\title{
Kajian Literasi Media Digital Library Universitas Brawijaya (Studi Kasus Pada Mahasiswa Tuna Netra Universitas Brawijaya)
}

\author{
Anita Tri Widiyawati \\ Universitas Brawijaya Malang \\ Email: anitatriwidiyawati@gmail.com/anitatriw@ub.ac.id
}

\begin{abstract}
The library is the heart of a university that has such extensive benefits. The existence of a library also supports the continuation of the Tri Dharma of Higher Education. The influence and utilization of technology (Digital Library), balanced with basic retention in the use of technology, can make it easier for students with disabilities to get information and facilitate communication with others. Therefore, it is important for the environment both the family environment and friendly environment to introduce the use and use of electronic goods. Through this research, it is known the Digital Library media literacy study on Universitas Brawijaya Blind Students. This study aims to analyze the media literacy of the blind for the Digital Library of Universitas Brawijaya and to find out the supporting factors and factors that inhibit the mastery of media literacy for the blind to the Digital Library of Universitas Brawijaya. This study uses a type of case study research with a qualitative approach while data collection in this study uses qualitative observation techniques, qualitative interviews, reviews information obtained through documents, audio-visual material, and documentation results during the research process.
\end{abstract}

Keywords: Media Literacy; Digital Library; Blind Students; Universitas Brawijaya

\begin{abstract}
Abstrak
Perpustakaan merupakan jantung dari sebuah Perguruan Tinggi memiliki manfaat yang begitu luas. Adanya perpustakaan juga menunjang keberlangsungan Tri Dharma Perguruan Tinggi. Pengaruh dan pemanfaatan teknologi (Digital Library) dengan diimbangi pengetahuan dasar dalam pemanfaatan teknologi dapat mempermudah mahasiswa penyandang disabilitas tuna netra untuk mendapatkan informasi maupun memudahkan komunikasi dengan orang lain. Oleh karena itu, penting bagi lingkungan baik lingkungan keluarga maupun lingkungan pertemanan untuk mengenalkan pemanfaatan dan penggunaan barang elektronik. Melalui penelitian ini
\end{abstract}


diketahui kajian literasi media Digital Library pada Mahasiswa Tuna Netra Universitas Brawijaya. Penelitian ini bertujuan untuk menganalisis literasi media penyandang tuna netra terhadap Digital Library Universitas Brawijaya serta mengetahui faktor pendukung dan faktor penghambat penguasaan literasi media penyandang tuna netra terhadap Digital Library Universitas Brawijaya. Penelitian ini menggunakan jenis penelitian studi kasus dengan pendekatan kualitatif sedangkan pengumpulan data dalam penelitian ini menggunakan teknik observasi kualitatif, wawancara kualitatif, mengkaji informasi yang didapat melalui dokumen, materi audio-visual, maupun hasil dokumentasi pada saat proses penelitian.

Kata Kunci: Literasi Media; Digital Library; Mahasiswa Tuna Netra; Universitas Brawijaya

\section{A. PENDAHULUAN}

Seleksi Program Khusus Penyandang Disabilitas (SPKPD) adalah seleksi penerimaan mahasiswa baru Universitas Brawijaya (UB) yang diperuntukkan bagi penyandang disabilitas. Panitia SPKPD akan melakukan rangkaian seleksi terhadap calon mahasiswa penyandang disabilitas yang memiliki kapabilitas sesuai dengan jurusan yang dipilih. Setiap penyandang disabilitas memiliki kesempatan untuk memperoleh beasiswa sesuai dengan persyaratan masing-masing beasiswa. Terdapat 110 mahasiswa difabel sampai bulan Juni 2018 dan terdapat 11 mahasiswa tuna netra yang tersebar di beberapa program studi dan fakultas di Universitas Brawijaya.

Di tahun akademik 2018/2019, Universitas Brawijaya kembali menerima mahasiswa difabel melalui jalur SPKPD sehingga kemungkinan jumlah mahasiswa tuna netra akan terus bertambah. Dan berdasarkan kenyataan di lapangan, mahasiswa penyandang disabilitas khususnya tuna netra masih sulit untuk lulus. Hal ini disebabkan mahasiswa tuna netra mempunyai keterbatasan penglihatan dalam belajar dan mengakses informasi yang dibutuhkan dalam mengikuti proses belajar mengajar. Tuna netra tidak saja mengarah pada mereka yang buta, tetapi mencakup juga mereka yang mampu melihat tetapi sangat terbatas dan kurang dapat dimanfaatkan untuk kepentingan hidup sehari-hari terutama dalam belajar. Jadi, individu dengan kondisi penglihatan yang termasuk "setengah melihat", "low vision", atau rabun adalah bagian dari kelompok anak tunanetra (Somantri, 2007: 65).

Perpustakaan merupakan sarana mahasiswa dalam mendapatkan informasi yang dibutuhkan untuk mendukung proses belajar mengajar, termasuk dalam mengerjakan tugas. Mahasiswa tuna netra mempunyai 
seorang pendamping/volunteer untuk membantu mereka dalam menjalankan aktivitas perkuliahan. Dalam perkembangannya, Universitas Brawijaya menyediakan koleksi-koleksi digital yang termaktub lengkap di website perpustakaan (digital library). Hal ini bertujuan untuk memberikan kemudahan bagi mahasiswa dalam mengakses dan mendapatkan informasi. Menurut Pendit (2008: 10) menjelaskan perpustakaan digital merupakan sebuah sistem yang melibatkan infrastruktur yang melibatkan teknologi informasi, manusia dan kebijakan, hubungan sosial (pemakai, perancang sistem, administrator, developer sistem) untuk memenuhi keperluan masyarakat pemakai.

Minimnya sosialisasi cara menelusur digital library bagi penyandang disabilitas, khususnya tuna netra menyebabkan ketidaktahuan mereka dalam memanfaatkan digital library secara maksimal. Banyak mahasiswa tuna netra yang langsung mencari informasi lewat internet secara umum/luas, sehingga informasi yang didapatkan seringkali tidak valid atau tidak bersumber dari referensi yang jelas. Berdasarkan permasalahan tersebut, perlu adanya kajian terkait literasi media mahasiswa tuna netra terhadap digital library. Tujuan penelitian ini adalah untuk mengetahui sejauh mana kemampuan mahasiswa tuna netra dalam melaksanakan aktivitas perkuliahan dengan memanfaatkan digital library yang dikemas dalam dua rumusan masalah sekaligus tujuan dari penelitin ini, adapun rumusan masalah dalam penelitian ini ialah (1) Bagaimanakah literasi media penyandang tuna netra terhadap digital library Universitas Brawijaya?. (2) Apa sajakah faktor pendukung dan faktor penghambat penguasaan literasi media penyandang tuna netra terhadap digital library Universitas Brawijaya?.

Penelitian ini menggunakan jenis penelitian studi kasus dengan pendekatan kualitatif tipe studi kasus tunggal (studi dalam-situs) (Creswell, 2015). Sumber data primer dan sumber sekunder digunakan pada penelitian ini. Teknik pengumpulan data yang dilaksanakan adalah observasi, wawancara, dokumentasi, materi audio-visual (Creswell, 2016). Teknik analisis data yang digunakan dalam penelitian ini adalah analisis data penelitian kualitatif Creswell. Adapun proses penerapan langkah-langkah analisis data penelitian kualitatif Creswell (2016: 263-268) sebagai berikut: langkah (1) mengolah dan mempersiapkan data untuk dianalisis; langkah (2) membaca keseluruhan data; langkah (3) memulai coding semua data; langkah (4) terapkan proses coding untuk mendeskripsilam setting (ranah), orang (informan), kategori dan tema yang akan dianalisis; langkah (5) tunjukkan bagaimana deskripsi dan tema-tema ini akan disajikan kembali dalam 
narasi/laporan kualitatif; dan langkah (6) pembuatan interpretasi dalam penelitian kualitatif atau memaknai data.

\section{B. HASIL DAN PEMBAHASAN}

\section{Perpustakaan Perguruan Tinggi}

Perpustakaan merupakan bagian dari lembaga ilmiah yang memfasilitasi kegiatan pendidikan tinggi yang bersangkutan. Nurlistiani (2017:2) menjelaskan perpustakaan perguruan tinggi menyediakan berbagai macam sumber informasi dan pengetahuan yang diperlukan untuk menunjang proses kegiatan belajar-mengajar (pendidikan), penelitian dan juga sumber referensi untuk kegiatan pengabdian masyarakat yang dilakukan oleh sivitas akademika. Lebih lanjut, Yusup (2016: 174-176) menjelaskan perpustakaan perguruan tinggi sebagai pusat sumber informasi yang menyediakan segala informasi yang mendukung kelancaran terlaksananya program-program akademik serta sebagai pusat sumber belajar bersama untuk sivitas akademika dan anggotanya.

Tujuan didirikannya perpustakaan perguruan tinggi adalah untuk mendukung kinerja perguruan tinggi dalam menyelenggarakan pendidikan dengan menyediakan sumber-sumber informasi ilmiah dan selalu melayani pengguna selama melaksanakan pendidikan. Agar tujuan ini dapat terlaksana, maka perpustakaan harus menjalankan fungsinya dengan baik. Direktorat Jenderal Perguruan Tinggi (2004:3) mendefinisikan fungsi perpustakaan perguruan tinggi sebagai berikut:

1. Fungsi Edukasi, Perpustakaan merupakan sumber belajar para civitas akademika, oleh karena itu koleksi yang disediakan adalah koleksi yang mendukung pencapaian tujuan pembelajaran, pengorganisasian bahan pembelajaran setiap program studi, koleksi tentang strategi belajar mengajar dan materi pendukung pelaksanaan evaluasi pembelajaran.

2. Fungsi Informasi, Perpustakan merupakan sumber informasi yang mudah diakses oleh pencari dan pengguna informasi.

3. Fungsi Riset, Perpustakaan mempersembahkan bahan-bahan primer dan sekunder yang paling mutakhir sebagai bahan untuk melakukan penelitian dan pengkajian ilmu pengetahuan, teknoologi dan seni.

4. Fungsi Rekreasi, Perpustakaan harus menyediakan koleksi rekreatif yang bermakna untuk membangun dan mengembangkan kreativitas, minat dan daya inovasi pengguna perpustakaan. 
5. Fungsi Publikasi, Perpustakaan selayaknya juga membantu melakukan publikasi karya yang dihasilkan oleh warga perguruan tingginya yakni civitas akademika dan staf non-akademik.

6. Fungsi Deposit, Perpustakaan menjadi pusat deposit untuk seluruh karya dan pengetahuan yang dihasilkan oleh warga perguruan tingginya.

7. Fungsi Interprestasi, Perpustakaan sudah seharusnya melakukan kajian dan memberikan nilai tambah terhadap sumber-sumber informasi yang dimilikinya untuk membantu pengguna dalam melakukan dharmanya.

\section{Perpustakaan Digital (Digital Library)}

Terdapat banyak definisi dan istilah tentang perpustakaan digital. Menurut International Federation of Library Associations and Institutions (IFLA) (2014: 1-2):

"Perpustakaan digital adalah kumpulan benda digital secara online, dengan kualitas terjamin, yang dibuat atau dikumpulkan dan dikelola sesuai dengan prinsip yang berlaku secara internasional untuk pengembangan koleksi dan dapat diakses secara koheren dan berkelanjutan, didukung oleh layanan yang diperlukan untuk memungkinkan pengguna mengambil dan memanfaatkan sumber daya. Perpustakaan digital demikian merupakan bagian integral dari layanan perpustakaan, yang menerapkan teknologi baru untuk menyediakan akses ke koleksi digital. Dalam perpustakaan digital, koleksi diciptakan, dikelola dan diakses sedemikian rupa sehingga tersedia dan tersedia secara ekonomis untuk digunakan oleh komunitas atau kumpulan masyarakat yang ditentukan".

Sementara Pendit (2008: 10) menjelaskan perpustakaan digital merupakan sebuah sistem yang melibatkan infrastruktur yang melibatkan teknologi informasi, manusia dan kebijakan, hubungan sosial (pemakai, perancang sistem, administrator, developer sistem) untuk memenuhi keperluan masyarakat pemakai. Sependapat dengan hal tersebut, Sun dan Yuan (2012: 13) menjelaskan perpustakaan digital adalah kumpulan perangkat komputasi, penyimpanan dan komunikasi digital bersama dengan konten dan perangkat lunak yang dibutuhkan untuk mereproduksi, meniru dan memperluas layanan untuk memenuhi kebutuhan pemakai.

Lebih lanjut Calhoun (2014) dalam Xie dan Matusiak (2016: 6) memperluas pemahaman tentang perpustakaan digital dengan menggabungkan architecture of digital library systems dan konsep open 
access. Calhoun mengusulkan sebuah definisi praktis yang menggabungkan beberapa komponen, termasuk sistem dan layanan,manajemen koleksi digital, ditujukan untuk memenuhi kebutuhan masyarakat, sebuah arsitektur sistem yang berpusat pada repositori, fitur pencarian, dan antarmuka pengguna. Definisi Calhoun berfokus pada infrastruktur teknis yang dibangun dengan sistem repositori, yang mencerminkan perkembangan perpustakaan digital terkini. Dari definisi di atas, dapat disimpulkan bahwa perpustakaan digital merupakah sebuah sistem menyediakan infrastuktur (teknologi), sumberdaya, koleksi digital dan layanan terkait untuk memenuhi kebutuhan pemakai atau komunitas.

\section{Karakteristik Perpustakaan Digital}

Menurut Sun dan Yuan (2012: 14) perpustakaan digital memiliki lima karakteristik sebagai berikut:

“(1) Perpustakaan yang melayani komunitas atau kumpulan komunitas yang ditentukan. (2) Kumpulan dari beberapa entitas. (3) Perpustakaan yang menggabungkan akses dan pembelajaran. (4) Perpustakaan yang menyediakan akses cepat dan efisien, dengan beberapa cara akses. (5) Perpustakaan dengan koleksi yang besar dan bertahan dari waktu ke waktu, terorganisir dengan baik dan dikelola, mengandung banyak format dan berisi benda-benda yang mungkin tidak dapat diperoleh".

Lebih lanjut Xie dan Matusiak (2016: 23) menjelaskan karakteristik perpustakaan digital sebagai berikut: Large collection size: kebanyakan berisi lebih dari satu juta item. Diverse formats: item koleksi berisi teks, gambar, audio dan video.General and specific collection development policy: tidak hanya berisi koleksi bidang umum,pedoman mutu dan tanggung jawab seleksi tetapi juga bergantung pada kebijakan anggota terkait koleksi. Copyright concern: beberapa dari mereka mungkin tidak memiliki izin hak cipta. Level of access: antarmuka tunggal untuk semua item koleksi; tergantung pada hak cipta, beberapa item memiliki akses teks penuh, sementara yang lain mungkin memiliki akses terbatas hanya pada kutipan atau abstrak. Interoperability: pemetaan metadata digunakan untuk memastikan pertukaran metadata antara koleksi, atau skema metadata tunggal diterapkan di semua koleksi.

Berdasarkan penjelasan di atas, dapat ditarik kesimpulan tentang karakteristik perpustakaan digital yang pada intinya adalah pemakai, koleksi digital, dan teknologi. Perpustakaan digital berupaya untuk memberikan 
kemudahan bagi komunitas/pemakainya dengan menyediakan berbagai layanan dan juga koleksi digital yang dimiliki.

\section{Koleksi Perpustakaan Digital}

Koleksi yang ada dalam perpustakaan digital adalah seluruh koleksi digital baik berbentuk teks, grafis, audio dan video. Menurut IFLA (2014: 2) sumber konten perpustakaan digital berisi digitised content dan born digital content. Born digital artinya materi terlahir dalam keadan digital, dibuat sebagai materi digital dan akan digunakan dan dipertahankan sebagai materi digital. Digitized content merupakan materi digital yang merupakan hasil konversi dari materi analog atau dokumen (Pendit, 2008: 34). Sementara menurut Johnson (2004: 200) koleksi digital atau sumber daya elektronik mencakup banyak jenis, format serta media penyimpanan dan pengiriman,

"Berdasarkan jenis meliputi surat kabar, buku referensi, jurnal, buku nonfiksi, novel, indeks, abstrak, perangkat lunak (termasuk perangkat lunak pendidikan) dan dokumen elektronik. Berdasarkan formatnya meliputi data numerik dan geospasial, gambar, teks, video, dan audio. Berdasarkan media penyimpanan dan pengiriman meliputi CD-ROM, magnetic tape, atau server diakses melalui jaringan".

Lebih lanjut Witten,et.al (2010: 127-284) menjelaskan material yang terdapat pada perpustakaan digital yang direpresentasikan pada tabel berikut.

Tabel 2. Material yang terdapat dalam perpustakaan digital

\begin{tabular}{|l|l|l|}
\hline $\begin{array}{l}\text { No } \\
\cdot\end{array}$ & Format & Material \\
\hline 1. & Text & $\begin{array}{l}\text { 1. Representing Textual Documents: ASCII, Unicode dan } \\
\text { plaintext } \\
\text { 2. Web Documents: HTML dan XML } \\
\text { 3. Presenting Web Documents : CSS dan XSL } \\
\text { 4. Page Description Languages : PostScript dan Portable } \\
\text { Document Format (PDF) } \\
\text { 5. Word-Processor Documents: Rich Text Format (RTF), } \\
\text { native word format, office open XML(OOXML), Open } \\
\text { Document Format (ODF), dan Scientific document } \\
\text { (LaTeX) } \\
\text { 6. Other Documents : file spreadsheets dan presentations, }\end{array}$ \\
\hline
\end{tabular}


8 | Anita Tri Widiyawati: Kajian Literasi Media...

\begin{tabular}{|l|l|l|}
\hline & & E-mail \\
\hline 2. & Audio & $\begin{array}{l}\text { 1. Pulse code modulation (PCM) } \\
\text { 2. Early format:WAV, AIFF, AU } \\
\text { 3. MPEG audio (MP3) } \\
\text { 4. Post-MP3 formats : AAC, Ogg Vorbis, dan FLAC }\end{array}$ \\
\hline 3. & Images & $\begin{array}{l}\text { 1. Lossless compression :GIF, PNG } \\
\text { 2. Lossless compression: JPEG } \\
\text { 3. Archiving images: JPEG 2000, dan TIFF } \\
\text { 4. Vector graphics images: Scalable Vector Graphics } \\
\text { (SVG) }\end{array}$ \\
\hline 4. & Video & $\begin{array}{l}\text { 1. Multimedia compression: MPEG-1, MPEG-2, MPEG- } \\
\text { 4), } \\
\text { 2. Proprietary formats : AVI, ASF dari Microsoft, } \\
\text { QuickTime dari Apple, FLV dari adobe, RealMedia dari } \\
\text { Real Network) dan Ogg Theora }\end{array}$ \\
\hline 5. & $\begin{array}{l}\text { Richmedi } \\
\text { a }\end{array}$ & $\begin{array}{l}\text { 1. Synchronized Multimedia Integration Language (SMIL) } \\
\text { dari W3C) } \\
\text { 2. Adobe Flash dari adobe } \\
\text { 3. Musical Instrument Digital Interface (MIDI) untuk } \\
\text { musik }\end{array}$ \\
\hline
\end{tabular}

Sumber: Witten,et.al, 2010 dengan olahan peneliti

Dari penjelasan tabel di atas, format dan material yang ada dalam perpustakaan digital pada umumnya meliputi format text, audio, images, video dan richmedia. Koleksi berbentuk digital ini pada intinya ditunjukkan untuk memenuhi kebutuhan pemakai yang semakin beragam dan bervariasi. Selain itu, koleksi digital menjadi salah satu aspek pendukung untuk mewujudkan tujuan dan fungsi perpustakaan digital.

\section{Tujuan dan Fungsi Perpustakaan Digital}

Perpustakaan digital memiliki tujuan dan fungsi untuk kepentingan pemakai maupun untuk kepentingan organisasi. Menurut IFLA (2014: 2) misi perpustakaan digital adalah memberikan akses langsung ke sumber informasi, baik digital maupun non-digital, secara terstruktur sehingga 
menghubungkan teknologi informasi, pendidikan dan budaya dalam layanan perpustakaan modern. Untuk memenuhi misi ini, tujuan perpustakaan digital harus dicapai sebagai berikut:

a. Mendukung digitalisasi, akses dan pelestarian warisan budaya dan ilmiah.

b. Menyediakan akses untuk semua pemakai ke sumber informasi yang dikumpulkan oleh perpustakaan, menghargai hak kekayaan intelektual.

c. Menciptakan sistem perpustakaan digital interoperabel untuk mempromosikan dan akses standar terbuka.

d. Mendukung peran penting perpustakaan dan layanan informasi dalam mempromosikan standar umum dan praktik terbaik.

e. Menciptakan kesadaran akan kebutuhan mendesak untuk memastikan akses tetap materi digital.

f. Menghubungkan perpustakaan digital ke jaringan penelitian dan pengembangan berkecepatan tinggi.

g. Mengambil keuntungan dari meningkatnya konvergensi media komunikasi dan peran institusional untuk menciptakan dan menyebarkan konten digital. (IFLA, 2014: 2)

Selain tujuan yang hendak dicapai perpustakaan digital, perpustakaan memiliki beberapa fungsi perpustakaan digital. Fungsi perpustakaan digital menurut Witten, et.al (2010: 26-28) dalam pengembangan suatu negara khususnya negara berkembang, yaitu:

a. Disseminating humanitarian information

Perpustakaan digital mendesiminasikan informasi untuk digunakan masyarakat secara bersama-sama dan cuma-cuma contohnya dengan bantuan dari organisasi internasional nonprofit seperti U.S. Peace Corps. U.S.

b. Disaster relief

Perpustakaan digital menggabungkan informasi dan pengetahuan seperti sifat bencana, area geografis, dan sumber logistik obat-obatan untuk kebutuhan dan kepentingan masyarakat.

c. Preserving indigenous culture

Perpustakaan digital melestarikan dan mengintegrasikan informasi tentang budaya lokal untuk memenuhi kebutuhan masyarakat serta sebagai upaya menyelamatkan budaya lokal.

d. Locally produced information 
Perpustakaan digital memberikan wadah bagi masyarakat untuk membuat konten lokal sesuai adat, tradisi dan budaya yang dimiliki.

\section{e. The technological infrastructure}

Perpustakaan digital memberikan alternatif penggunaan media desimanasi dengan menggunakan recordable devices (CD atau DVD) untuk daerah berkembang untuk menyediakan informasi berbentuk digital.

Berdasarkan penjelasan tujuan dan fungsi di atas, pada dasarnya perpustakaan digital berusaha untuk menyedikan akses, layanan dan koleksi digital secara cepat dan praktis untuk memenuhi kebutuhan intelektual pemakainya. Penyediaan akses, layanan dan koleksi digital tersebut dapat memberikan keuntungan bagi berbagai pihak seperti pemakai, komunitas, organisasi dan negara.

\section{Keuntungan Perpustakaan Digital}

Melihat tujuan dan fungsi yang dibahas dalam poin sebelumnya, perpustakaan digital sebenarnya memiliki keuntungan tersendiri. Menurut Mishra (2016: 2) keuntungan perpustakaan digital, antara lain:

a. No physical boundary: Pemakai tidak perlu pergi ke perpustakaan secara fisik; pemakai dari seluruh dunia dapat memperoleh akses ke informasi yang sama, selama koneksi internet tersedia.

b. Round the clock availability: Pemakai dapat mengakses informasi kapan saja(24 jam/7 minggu) dan dimana saja.

c. Multiple accesses: Sumber daya yang sama bisa digunakan bersamaan oleh sejumlah institusi dan patron.

d. Information retrieval: Pemakai dapat menggunakan istilah penelusuran apa pun (kata, frasa, judul, nama, dan subjek) untuk menelusuri keseluruhan koleksi. Perpustakaan digital menyediakan antarmuka yang sangat ramah, memberikan akses yang dapat diklik ke sumber dayanya dengan benar.

e. Preservation and conservation: Digitalisasi bukanlah solusi pelestarian jangka panjang untuk koleksi fisik namun berhasil menyediakan salinan akses untuk bahan yang mudah rusak dari penggunaan berulang-ulang..

f. Space: Perpustakaan tradisional dibatasi oleh ruang penyimpanan, perpustakaan digital memiliki potensi untuk menyimpan lebih banyak informasi; karena informasi digital memerlukan sedikit ruang fisik untuk menampungnya dan media penyimpanan digital lebih terjangkau daripada sebelumnya. 
g. Added value: Karakteristik objek tertentu terutama kualitas gambar dapat ditingkatkan. Digitalisasi dapat meningkatkan keterbacaan dan menghilangkan kekurangan yang terlihat seperti noda dan perubahan warna.

h. Easily accessible: Perpustakaan digital menawarkan kemudahan akses bagi pemakai

Berdasarkan penjelasan di atas, keuntungan yang ditawarkan perpustakaan digital seyogyanya dapat dimanfaatkan oleh berbagai pihak seperti pemakai, komunitas,organisasi dan pihak lainnya. Perpustakaan digital dalam perspektif perpustakaan perguruan tinggi kemudian berkembang, kemudian diistilahkan repositori institusi. Repositori institusi merupakan bagian dari Perpustakaan digital dalam lingkup yang lebih sempit, lebih ditunjukkan pemakai (komunitas) tertentu serta koleksi digital yang umumnya berisi local content (lokal konten), literatur kelabu dan karya intelektual perguruan tinggi.

\section{Penyandang Tuna Netra}

Indera penglihatan merupakan salah satu indera penting dalam menerima informasi yang datang dari luar dirinya. Sekalipun cara kerjanya dibatasi oleh ruang, indera ini mampu melakukan pengamatan terhadap dunia sekitar, tidak saja pada bentuknya (pada objek berdimensi dua) tetapi juga pengamatan dalam (pada objek berdimensi tiga), warna dan dinamikanya. Melalui indera pula sebagian besar rangsang atau informasi akan diterima untuk selanjutnya diteruskan ke otak, sehingga timbul kesan atau persepsi dan pengertian tertentu terhadap rangsang tersebut. Melalui kegiatan-kegiatan yang bertahap dan terus menerus seperti inilah yang pada akhirnya mampu merangsang pertumbuhan dan perkembangan kognitif seseorang sehingga mampu berkembang secara optimal.

Dalam bidang pendidikan luar biasa, individu dengan gangguan penglihatan lebih akrab disebut dengan penyandang tuna netra. Pengertian tuna netra tidak saja mengarah pada mereka yang buta, tetapi mencakup juga mereka yang mampu melihat tetapi sangat terbatas dan kurang dapat dimanfaatkan untuk kepentingan hidup sehari-hari terutama dalam belajar. Jadi, individu dengan kondisi penglihatan yang termasuk "setengah melihat", "low vision", atau rabun adalah bagian dari kelompok anak tunanetra (Somantri, 2007: 65).

Dari uraian di atas, pengertian anak tuna netra adalah individu yang indera penglihatannya (keduaduanya) tidak berfungsi sebagai saluran 
penerima informasi dalam kegiatan sehari-hari seperti halnya orang awas. Dengan kata lain, tunanetra merupakan sebutan untuk individu yang memiliki hambatan dalam penglihatan atau tidak berfungsinya indera penglihatan.

\section{Karakteristik Umum Tuna Netra}

Dalam buku Psikologi Pendidikan, karya Jeanne Ellis Ormrod, disebutkan bahwa siswa yang mengalami gangguan visual biasanya memiliki beberapa atau semua dari karakteristik-karakteristik berikut ini:

1) Indera lainnnya berfungsi normal (pendengaran, sentuhan, dan sebagainya).

2) Secara umum memiliki kemampuan belajar yang sama dengan siswa normal.

3) Perbendaharaan kata dan pengetahuan umu yang lebih terbatas, sebagian disebabkan oleh terbatasnya kesepatan untuk mengalami dunia luar melalui fasilitas pendidikan (misalnya: kurang mampu melihat peta, film, dan materi-materi visual lainnya).

4) Menurunnya kapasitas untuk meniru perilaku orang lain.

5) Tidak mampu mengamati bahasa tubuh orang lain dan tanda-tanda nonverbal yang membuat mereka terkadang keliru memahami pesan-pesan orang lain.

6) Merasa bingung dan cemas (khususnya di tempat orang lalu lalang seperti di ruang makan atau taman bermain) karena memiliki pengetahuan yang terbatas mengenai peristiwa-peristiwa yang sedang berlangsung). (Ormrod, 2008: 252).

\section{Klasifikasi Tuna Netra}

Ada beragam klasifikasi pada tuna netra, namun pada dasarnya tuna netra dibagi menjadi dua kelompok, yaitu kurang penglihatan (low vision) dan buta total (totally blind). Kurang penglihatan (low vision), yakni mereka yang memiliki pandangan yang kabur ketika melihat suatu objek, sehingga untuk mengatasi permasalahan penglihatannya, penderita tunanetra jenis low vision perlu menggunakan kacamata atau kotak lensa. Sedangkan, yang dimaksud buta total (totally blind), yakni mereka yang sama sekali tidak mampu melihat rangsangan cahaya dari luar (Smart, 2010: 36).

Menurut Direktorat Pembinaan Sekolah Luar Biasa, tuna netra secara garis besar dapat dikelompokkan berdasarkan empat kategori, yaitu: 1) waktu terjadinya ketuna-netraan, 2) kemampuan daya penglihatan, 3) pemeriksaan 
klinis, dan 4) kelainankelainan pada mata (Hartono, 2010: 195). Keempat klasifikasi ketunanetraan itu dijelaskan sebagai berikut:

1. Berdasarkan waktu terjadinya ketunanetraan, ada lima kategori tuna netra, yaitu sebagai berikut:

a) Tuna netra sebelum dan sejak lahir, yakni mereka yang sama sekali tidak memiliki pengalaman penglihatan.

b) Tuna netra setelah lahir atau pada usia kecil, yaitu mereka yang telah memiliki kesan-kesan serta pengalaman visual, tetapi belum kuat dan mudah terlupakan.

c) Tuna netra pada usia sekolah atau pada masa remaja, yaitu mereka yang yang telah memiliki kesan-kesan visual dan meninggalkan pengaruh yang mendalamm terhadap proses perkembangan pribadi.

d) Tuna netra pada usia dewasa, yaitu pada umumnya mereka yang dengan segala kesadaran mampu melakukan latihan-latihan penyesuaian diri.

e) Tuna netra dalam usia lanjut, yaitu sebagian besar sudah sulit mengikuti latihan-latihan penyesuaian diri.

2. Berdasarkan kemampuan daya penglihatan, tuna netra ddibagi menjadi 3 kategori sebagai berikut:

a) Tuna netra ringan (defective vision/low vision), yakni mereka yang memiliki hambatan dalam penglihatan, tetapi mereka yang mengikuti program-program pendidikan dan mampu melakukan pekerjaan/kegiatan yang menggunakan fungsi penglihatan.

b) Tuna netra setengah berat (partially sighted), yakni mereka yang kehilangan sebagian daya penglihatan, hanya dengan menggunakan kaca pembesar mampu mengikuti pendidikan biasa atau mampu membaca tulisan yang bercetak tebal.

c) Tuna netra berat (totally blind), yakni mereka yang sama sekali tidak bisa melihat. (Hartono, 2010: 195)

3. Berdasarkan pemeriksaan klinis, tuna netra dibagi menjadi 2 kategori sebagai berikut:

a) Tuna netra yang memiliki ketajaman penglihatan kurang dari 20/200 dan atau memiliki bidang penglihatan kurang dari 20 derajat.

b) Tuna netra yang masih memiliki ketajaman penglihatan antara20/70 sampai dengan 20/200 yang dapat lebih baik melalui perbaikan.

4. Berdasarkan kelainan pada mata, tuna netra dibagi menjadi 3 kategori sebagai berikut: 
a) Myopia, yaitu penglihatan jarak dekat, bayangan tidak terfokus dan jatuh di belakang retina. Penglihatan akan menjadi jelas kalau objek didekatkan. Untuk membantu proses penglihatan pada penderita myopia digunakan kacamata proyeksi dengan lensa negatif.

b) Hyperopia, yaitu penglihatan jarak jauh, bayangan tidak terfokus, dan jatuh tepat di retina. Penglihatan akan menjadi jelas jika objek dijauhkan. Untuk membantu proses penglihatan pada penderita hyperopia digunakan kacamata koreksi dengan lensa positif.

c) Astigmatisme, yaitu penyimpangan atau penglihatan kabur yang disebabkan karena ketidakberesan pada kornea mata atau pada permukaan lain pada bola mata sehingga bayangan benda baik pada jarak dekat maupun jauh tidak terfokus jatuh pada retina. Untuk membantu proses penglihatan pada penderita astigmatisme digunakan kacamata koreksi dengan lensa silindris. (Hartono, 2010: 196)

\section{Faktor Penyebab Tuna Netra}

Secara ilmiah, tuna netra dapat disebabkan oleh faktor internal, meliputi: prenatal dan post natal.10 Berikut penjelasannya:

1. Pre Natal (dalam kandungan)

Faktor ini erat kaitannya dengan adanya riwayat dari orang tuanya atau adanya kelainan pada masa kehamilan. Faktor ini meliputi:

a) Keturunan

Pernikahan dengan sesama tuna netra dapat menghasilkan keturunan dengan kekurangan yang sama yaitu tunanetra. Selain itu juga bisa disebabkan jika salah satu orangtua memiliki riwayat tunanetra. Ketunanetraan akibat faktor keturunan antara lain Retinis Pigmentosa, yaitu penyakit pada retina yang umumnya merupakan keturunan.

b) Pertumbuhan anak dalam kandungan

Faktor ini dapat disebabkan oleh gangguan saat ibu masih hamil; adanya penyakit menahun seperti TBC, sehingga merusak sel-sel darah tertentu selama pertumbuhan janin dalam kandungan; infeksi atau luka yang dialami oleh ibu hamil nakibat terkena rubella atau cacar air dpat menyebabkan kerusakan pada mata, telinga, dan sistem susunan saraf pusat pada janin yang sedang berkembang; serta kekurangan vitamin tertentu yang dapat menyebabkan gangguan pada mata sehingga kehilangan fungsi penglihatan.

2. Post Natal 
Post Natal merupakan masa setelah bayi dilahirkan, meliputi:

a) Kerusakan pada mata atau saraf mata pada waktu persalinan, akibat benturan alat-alat atau benda keras;

b) Pada waktu persalinan, ibu mengalami penyakit gonorrhoe sehingga baksil gonorrhoe menular pada bayi, yang pada akhirnyan setelah bayi lahir mengalami sakit dan berakibat hilangnya daya penglihatan;

c) Mengalami penyakit mata yang menyebabkan ketunanetraan.

d) Kerusakan mata yang disebabkan oleh terjadinya kecelakaan, seperti masuknya benda keras atau tajam, cairan kimia yang berbahaya, atau kecelakaan dari kendaraan.

\section{Kondisi Kecerdasan Penyandang Tuna Netra}

Berdasarkan kesimpulan hasil penelitian Heyes (seorang ahli pendidikan tunanetra) terhadap kondisi kecerdasan anak tuna netra, yang dikutip oleh Mohammad Efendi (2009: 44) menyimpulkan bahwa:

1. Ketunanetraan tidak secara otomatis mengakibatkan kecerdasan rendah.

2. Mulainya ketunanetraan tidak mempengaruhi tingkat kecerdasan.

3. Anak tuna netra ternyata banyak yang berhasil mencapai prestasi intelektual yang baik, apabila lingkungan memberikan kesempatan dan motivasi kepada anak tuna netra untuk berkembang.

4. Penyandang ketunanetraan tidak menunjukkan kelemahan dalam intelegensi verbal.

Kesimpulan hasil penelitian di atas, setidaknya menegaskan bahwa pada dasarnya kondisi kecerdasan anak tuna netra tidak berbeda dengan anak normal umumnya. Apabila diketahui kecerdasan anak tuna netra lebih rendah dari anak normal pada umumnya, hal tersebut disebabkan karena anak tuna netra memiliki hambatan persepsi, berpikir secara komprehensif dan mencari rangkaian sebab akibat. Bahkan jika dikonversikan dengan fase perkembangan kognitif dari Piaget, perkembangan kognitif anak tuna netra pada tingkat sensomotorik terhambat kurang lebih 4 tahun, dan pada fase intuitif terhambat 2 tahun. Meskipun dalam proses berpikirnya tidak berbeda dengan anak normal. Cruickshank, sebagaimana dikutip oleh Mohammad Efendi (2009:44-45) menjelaskan bahwa aplikasi terhadap struktur kecakapan anak tuna netra yang dapat digunakan sebagai dasar untuk mengkomparasikan dengan anak normal, antara lain: 
1. Anak tuna netra menerima pengalaman nyata yang sama dengan anak normal, dari pengamatan tersebut kemudian diintegrasikan ke dalam pengertiannnya sendiri.

2. Anak tuna netra cenderung menggunakan pendekatan konseptual yang abstrak menuju ke konkret, kemudian menuju fungsional serta terhadap konsekuensinya, sedangkan pada anak normal yang terjadi sebaliknya.

3. Anak tuna netra perbendaharaan kata-katanya terbatas pada definisi kata.

4. Anak tuna netra tidak dapat membandingkan, terutama dalam hal kecakapan numerik.

\section{Literasi Media}

Baran \& Denis (2012: 414) mendefinisikan literasi media sebagai "The ability to access, analyze, evaluate, and communicate messages". Definisi tersebut berarti bahwa literasi media adalah kemampuan untuk mengakses, menganalisis, mengevaluasi, dan menyampaikan pesan.

UNESCO Institute for Information Technologies in Education (IITE) mengungkapkan bahwa "As with the term media itself. media literacy has many different definitions. here we take the view that the core of media literacy is an analytical attitude toward media environment. being media critical and a courage to express oneself through media" (Seperti halnya dengan istilah media itu sendiri. Literasi media memiliki banyak definisi yang berbeda. Di sini kami mengambil pandangan bahwa inti literasi media adalah sikap analitis terhadap lingkungan media. menjadi media kritis dan berani mengekspresikan diri melalui media).

Adapun Center for Media Literacy dalam Potter (2010) mendefinisikan literasi media sebagai berikut:

"A framework for accessing, analyzing, evaluating and creating media. The development of critical thinking and production skills needed to live fully in the 21 st century media culture." Also defined as "the ability to communicate competently in all media forms, print and electronic, as well as to access, understand, and analyze and evaluate the powerful images, words and sounds that make up our contemporary mass media culture."

Uraian tersebut menunjukkan definisi literasi media adalah "Sebuah kerangka kerja untuk mengakses, menganalisis, mengevaluasi dan menciptakan media. Pengembangan pemikiran kritis dan keterampilan produksi diperlukan untuk hidup sepenuhnya dalam budaya media abad 21.', Juga didefinisikan sebagai "Kemampuan untuk berkomunikasi secara kompeten dalam semua bentuk media, cetak dan elektronik, seperti juga 
untuk mengakses, memahami, dan menganalisa serta mengevaluasi gambar yang kuat, kata-kata dan suara yang membentuk budaya media masa kontemporer kita.). Beberapa pendapat di atas dapat disimpulkan bahwa literasi media adalah kemampuan mengakses, mendayagunakan, menganalisis, dan mengevaluasi serta mampu berkomunikasi dalam semua bentuk media.

Teori literasi media menurut Potter (2004: 68-72) dikemas dalam model yang menampilkan empat faktor utama: struktur pengetahuan, lokus pribadi, kompetensi dan keterampilan, dan aliran tugas pemrosesan informasi. masing-masing faktor ini bekerja secara interaktif dalam suatu sistem.

\section{Struktur Pengetahuan}

Dasar untuk membangun melek media adalah struktur pengetahuan dasar berupa: pengaruh media, konten media, industri media, dunia nyata dan diri. Empat pengetahuan ini menjadikan seseorang lebih sadar selama proses pengolahan informasi dan karenanya lebih mampu membuat keputusan yang lebih baik tentang mencari informasi, bekerja dengan informasi itu, dan membangun makna darinya yang akan berguna untuk melayani. tujuan mereka sendiri.

\section{Lokus Pribadi}

Lokus pribadi adalah istilah yang mengacu pada apa yang mengatur tugas pemrosesan informasi atau apa yang memandu keputusan mereka. Oleh karena itu, menjadi lebih melek media berarti bahwa seseorang menggunakan lokus lebih banyak dan lebih aktif menggunakannya.

Lokus bekerja dalam sadar dan tidak sadar. Jika sadar maka orang akan dapat mengambil keputusan dan sebaliknya jika tidak sadar. Pada kedua keadaan ini struktur pengetahuan dapat dibentuk dan dikolaborasikan.

\section{Kompetensi dan Keterampilan}

Kompetensi dan Keterampilan bekerjasama dalam tugas pemrosesan informasi. Memiliki kompetensi tidak berarti menjadikan melek media, tapi kekurangan kompetensi mencegah seseorang melek media, karena mencegah seseorang mengakses informasi yang baik. Kompetensi dan Keterampilan bisa jadi lebih unggul satu sama lain, sehingga nilai dari keterampilan dan kompetensi individu didasarkan pada tantangan dalam pemrosesan informasi yang berbeda-beda.

\section{Aliran Tugas Pemrosesan Informasi}


Tiga tugas pemrosesan informasi adalah penyaringan informasi, pencocokan makna, dan membangun makna. Tugas ini dilakukan dalam rangkaian memproses informasi.

Setiap tugas bergantung pada keterampilan yang berbeda. Semakin banyak keterampilan orang yang dikembangkan, semakin banyak dia melek media. Setiap tugas bergantung pada struktur pengetahuan, semakin berkembang struktur pengetahuan seseorang, semakin banyak dia melek media.

\section{Literasi Media Penyandang Tuna Netra terhadap Digital Library Universitas Brawijaya}

Seperti yang telah dijelaskan sebelumnya bahwa dasar untuk membangun melek media adalah struktur pengetahuan dasar berupa: pengaruh media, konten media, industri media, dunia nyata dan diri. Empat pengetahuan ini menjadikan seseorang lebih sadar selama proses pengolahan informasi dan karenanya lebih mampu membuat keputusan yang lebih baik tentang mencari informasi, bekerja dengan informasi itu, dan membangun makna darinya yang akan berguna untuk melayani tujuan mereka sendiri.

Berdasarkan dari hasil analisis wawancara terhadap beberapa informan yang merupakan mahasiswa penyandang disabilitas tuna netra di Universitas Brawijaya Malang, dapat disimpulkan beberapa hal:

1) Struktur Pengetahuan

Dari hasil data yang telah disajikan dalam pembahasan sebelumnya, struktur pengetahuan merupakan salah satu komponen penting dalam penelitian. Dalam struktur pengetahuan terdapat empat pengetahuan yang dapat menjadikan seseorang lebih sadar selama proses pengolahan informasi, adapun empat pengetahuan tersebut ialah pengaruh media, konten media, industri media, dunia nyata dan diri.

Berdasarkan dari hasil analisis wawancara terhadap beberapa informan yang merupakan mahasiswa penyandang disabilitas tuna netra di Universitas Brawijaya Malang, dapat disimpulkan bahwa pada umumnya sebagian besar mahasiswa penyandang disabilitas tuna netra memiliki pengetahuan dasar dalam penggunaan, pemanfaatan dan juga akses Digital Library Universitas Brawijaya. Pengetahuan dasar ini informan dapatkan melalui berbagai sumber di antaranya lingkungan sekolah, PSLD, dan juga lingkungan pertemanan maupun dari kegiatan perkuliahan. Selain hal tersebut, pemilihan Program Studi juga mempengaruhi mahasiswa dalam 
memanfaatkan Digital Library. Pungky sebagai Mahasiswa Program Studi Perpustakaan dan Ilmu informasi memiliki pengetahuan dasar tentang penggunaan Digital Library lebih baik dan lebih mahir dari mahasiswa lain sebagai penyandang tuna netra.

Selain itu, beberapa mahasiswa penyandang tuna netra mengatakan bahwa mereka tidak pernah mengakses Digital Library milik Perpustakaan Universitas Brawijaya karena beberapa alasan di antaranya kurangnya sosialisasi dari pihak Perpustakaan Universitas Brawijaya dan pengenalan khusus kepada Mahasiswa penyandang tuna netra.

Pengaruh dan pemanfaatan teknologi dengan diimbangi pengetahuan dasar dalam pemanfaatan teknologi dapat mempermudah mahasiswa penyandang disabilitas tuna netra untuk mendapatkan informasi maupun memudahkan komunikasi dengan orang lain. Oleh karena itu, penting bagi lingkungan baik lingkungan keluarga maupun lingkungan pertemanan untuk mengenalkan pemanfaatan dan penggunaan barang elektronik. Mahasiswa penyandang disabilitas tuna netra dapat memahami informasi dengan mudah melalui aplikasi yang dapat memudahkan mereka, sehingga tidak ada alasan untuk mereka tidak bersosialisasi dengan kawan yang lainnya, maupun juga dalam pemenuhan informasi yang ia butuhkan.

2) Lokus Pribadi

Lokus pribadi merupakan istilah yang mengacu pada apa yang mengatur tugas pemrosesan informasi atau apa yang memandu keputusan mereka. Oleh karena itu, menjadi lebih melek media berarti bahwa seseorang menggunakan lokus lebih banyak dan lebih aktif menggunakannya. Lokus bekerja dalam sadar dan tidak sadar. Jika sadar maka orang akan dapat mengambil keputusan dan sebaliknya jika tidak sadar. Pada kedua keadaan ini struktur pengetahuan dapat dibentuk dan dikolaborasikan. Lokus pribadi inilah yang mempengaruhi seseorang mampu menentukan informasi yang ia butuhkan dengan tepat atau tidak.

Berdasarkan dari hasil analisis wawancara terhadap beberapa informan yang merupakan mahasiswa penyandang disabilitas tuna netra di Universitas Brawijaya Malang, di antaranya banyak informasi yang ia dapatkan dari hasil pencarian di sumber informasi salah satunya melalui Digital Library Universitas Brawijaya, mahasiswa penyandang disabilitas tuna netra dapat memutuskan informasi yang tepat sesuai dengan informasi yang sedang informan butuhkan. Beberapa mahasiswa mampu mencari sendiri informasi yang ia butuhkan dengan bantuan aplikasi seperti jaws namun ada beberapa informasi yang tidak dapat informan temukan sendiri 
karena ada bebarapa alasan contohnya ialah format dokumen informasi tidak support dengan aplikasi bantu yang digunakan, adapun informasi yang tidak dapat terbaca oleh aplikasi bantu informan ialah informasi dalam bentuk .jpg, .png, maupun hasil scan.

Dalam beberapa situasi yang tentunya mendukung mahasiswa tuna netra dalam mendapatkan informasi, seperti aplikasi pendukung yang membantu mereka membaca informasi yang di dapat tentu saja mahasiswa penyandang tuna netra tidak merasa kesulitan dalam menentukan dan menetapkan informasi yang ia dapatkan sudah sesuai atau tidak. Dalam beberapa kasus mahasiswa penyandang tuna netra membutuhkan bantuan orang lain terutama ketika aplikasi bantu yang mereka gunakan tidak support/mendukung.

3) Kompetensi dan Keterampilan

Kompetensi dan Keterampilan berkaitan erat dengan tiga tugas pemrosesan informasi. Adapun tiga tugas pemrosesan informasi tersebut ialah penyaringan informasi, pencocokan makna, dan membangun makna. Tugas ini dilakukan dalam rangkaian memproses informasi. Setiap tugas bergantung pada keterampilan yang berbeda. Semakin banyak keterampilan orang yang dikembangkan, semakin banyak dia melek media. Setiap tugas bergantung pada struktur pengetahuan, semakin berkembang struktur pengetahuan seseorang, semakin banyak dia melek media.

Dari hasil analisis wawancara terhadap Mahasiswa penyandang tuna netra di Universitas Brawijaya Malang dapat disimpulkan bahwa keterbatasan dalam kekurangan fisik mahasiswa penyandang tuna netra tidak membuat mereka untuk tidak mengikuti perkembangan teknologi. Pada dasarnya mahasiswa penyandang tuna netra dapat mengakses dan mendapatkan informasi melalui internet, salah satunya ialah dengan mengakses Digital Library Universitas Brawijaya.. Mahasiswa penyandang disabilitas tuna netra pada umumnya mengetahui berbagai macam sumber informasi di digital library Universitas Brawijaya (ebook, jurnal, video, OPAC, dll), namun tidak semuanya dapat diakses karena aplikasi pendukung yang mereka gunakan terkadang tidak support seperti tidak dapat membaca informasi dalam bentuk format .jpg, .png, maupun format foto dan hasil scan sehingga hanya informasi dalam bentuk dokumen saja yang dapat mereka gunakan. 
4) Aliran Tugas Pemrosesan Informasi

Tiga tugas pemrosesan informasi adalah penyaringan informasi, pencocokan makna, dan membangun makna. Tugas ini dilakukan dalam rangkaian memproses informasi. Selain itu mahasiswa juga dapat membedakan informasi yang valid dengan informasi yang tidak valid dengan melihat penulis maupun copyright. Dalam keterbatasan informan, ternyata tidak menjadikan alasan untuk tidak mengetahui informasi yang valid dan tidak valid. Dari hasil wawancara dapat disimpulkan bahwa informan mampu mengidentifikasi informasi yang valid dan informasi yang tidak valid dengan cara melihat dari pengarang maupun copyright.

Adapun faktor penghambat dalam penguasaan literasi media penyandang tuna netra terhadap penerapan Digital Library Universitas Brawijaya, harapannya dapat dipertimbangkan dan melakukan perbaikan sehingga informasi yang disediakan tidak hanya dapat dimanfaatkan oleh mahasiswa normal saja, namun juga mahasiswa penyandang disabilitas. Secara keseluruhan, dapat disimpulkan bahwa Mahasiswa Penyandang Disabilitas Tuna Netra dapat menguasai Literasi Media terhadap Digital Library dengan bantuan aplikasi maupun dengan bantuan orang lain yang memberikan pelatihan maupun pembekalan dalam mengakses dan penggunaan media.

\section{Faktor Pendukung dan Faktor Penghambat Penguasaan Literasi Media Penyandang Tuna Netra terhadap Digital Library Universitas Brawijaya}

Dalam penerapan Digital Library, terdapat faktor pendukung yang dapat membantu mahasiswa penyandang tuna netra dalam penguasaan literasi media, dan juga terdapat faktor penghambat yang menyulitkan mahasiswa penyandang tuna netra dalam penguasaan literasi media Digital Library. Berdasarkan hasil wawancara terhadap mahasiswa penyandang disabilitas tuna netra, dapat disimpulkan bahwa penerapan Digital Library masih memiliki banyak faktor penghambat penguasaan Literasi Media penyandang tuna netra, di antaranya: a) OPAC tidak dilengkapi dengan aplikasi bantu penyandang disabilitas, sehingga penyandang tuna netra kesulitan dalam akses OPAC di perpustakaan; b) banyaknya koleksi ataupun informasi yang tidak support dengan aplikasi bantu penyandang tuna netra membuat mahasiswa kesulitan dalam mendapatkan informasi yang dibutuhkan; c) tidak ada volunteer/pustakawan khusus yang membantu mahasiswa penyandang disabilitas ketika ia di perpustakaan; dan d) tidak ada sosialisasi dari perpustakaan terkait digital library bagi mahasiswa tuna netra. 
Adapun faktor pendukungnya adalah: a) perpustakaan telah memberikan akses bagi mahasiswa tuna netra dengan menekankan adanya volunteer yang harus menemani mahasiswa saat berkunjung ke perpustakaan atau pada saat menggunakan digital library di perpustakaan; b) adanya sosialisasi per-individu yang dilakukan oleh PSLD walaupun masih belum maksimal; serta c) dosen yang secara tidak langsung telah menjadi pendorong bagi mahasiswa tuna netra untuk menguasai literasi media digital library melalui tugas kuliah. Dari hasil analisis tersebut dapat disimpulkan bahwa konsep Digital Library dapat dimanfaatkan oleh mahasiswa penyandang tunan netra, namun masih ada beberapa hal yang masih menjadi kendala mahasiswa tuna netra dalam proses penguasaan literasi media.

\section{KESIMPULAN}

Perpustakaan Universitas Brawijaya Malang merupakan salah satu wadah bagi mahasiswa untuk memnuhi kebutuhan informasi yang menunjang Tri Dharma Perguruan Tinggi. Kebutuhan informasi ini juga dimanfaatkan oleh mahasiswa penyandang disabilitas utamanya mahasiswa penyandang tuna netra. Dari penelitian yang dilakukan oleh penulis berlatar belakang dari dua indikator. Indikator yang pertama bertujuan untuk mengetahui Pengetahuan Dasar Literasi Media Digital Library bagi mahasiswa penyandang disabilitas tuna netra di Universitas Brawijaya, selanjutnya bertujuan untuk mengetahui faktor pendukung dan faktor penghambat penguasaan literasi mahasiswa penyandang disabilitas tuna netra dalam penguasaan literasi media terhadap digital library Universitas Brawijaya. Dari hasil penelitian dapat disimpulkan bahwa :

1. Sebagian besar, mahasiswa penyandang tuna netra telah memiliki bekal berupa pengetahuan dasar terkait pengaruh media, konten media, industri media dan juga pengetahuan dasar mengenai pembelajaran ketika menggunakan digital library Universitas Brawijaya, sehingga beberapa mahasiswa merasa tidak mengalami kesulitan dalam menggunakan dan memanfaatkan media digital library Universitas Brawijaya.

2. Beberapa Mahasiswa Penyandang Tuna Netra tidak pernah mengakses Digital Library milik Perpustakaan Universitas Brawijaya dikarenakan kurangnya sosialisasi pengenalan dan pemanfaatan Digital Library.

3. Mahasiswa penyandang tuna netra dapat memutuskan sendiri informasi yang dibutuhkan dengan tepat ketika memanfaatkan pembelajaran melalui Idigital library Universitas Brawijaya.

4. Mahasiswa penyandang tuna netra memiliki kompetensi dan keterampilan dalam pencarian informasi melalui digital library. Mahasiswa dapat 
mencari informasi dengan mudah melalui digital library namun dengan bantuan aplikasi khusus penyandang tunan netra seperti aplikasi Jaws untuk digunakan di pc/leptop dan aplikasi talkback yang digunakan di smartphone. Mahasiswa hanya dapat mengakses informasi dalam bentuk format tertentu saja, ada beberapa informasi yang tidak dapat diakses dengan menggunakan aplikasi bantu yang digunakan mahasiswa contohnya informasi dalam bentuk gambar dan hasil scan

5. Mahasiwa penyandang tuna netra memiliki dasar pengetahuan mengenai informasi yang valid dan informasi yang tidak valid sehingga mahasiswa dapat membedakan informasi yang ia dapatkan merupakan informasi valid atau tidak dengan melihat penulis dan rightcopy.

6. Mahasiswa dibantu aplikasi Jaws dan Talkback, mampu memahami informasi yang telah ia dapatkan melalui digital library Universitas Brawijaya. Selalin memahami, mahasiswa penyandang tuna netra juga mampu menangkap makna dari nformasi yang ia dapatkan sehingga mahasiswa mampu merangkai makna dan kesimpulan dari informasi yang ia dapatkan.

7. Digital library Universitas Brawijaya memiliki banyak sumber informasi baik dalam bentuk e-book maupun e-journal yang dapat dimanfaatkan oleh civika akademika Universitas Brawijaya, termasuk mahasiswa penyandang tuna netra. Namun informasi yang ada dalam database $e$-book maupun e-journal yang dilanggan Universitas Brawijaya tidak semuanya dapat diakses oleh mahasiswa penyandang tuna netra. Untuk pencarian informasi, mahasiswa penyandang tuna netra memanfaatkan aplikasi bantu seperti Jaws dan Talkback, namun dari digital library Universitas Brawijaya banyak dijumpai bentuk format dokumen hasil pencarian informasi yang tidak support dengan aplikasi bantu yang digunakan mahasiswa penyandang tuna netra, sehingga mahasiswa merasa kesulitan dalam memahami informasi. Tidak jarang jika mahasiswa penyandang tuna netra meminta bantuan PSLD untuk mengubah bentuk format informasi baik itu berupa gambar maupun hasil scan ke dalam bentuk Ms. Word.

\section{DAFTAR RUJUKAN}

Baran, S.J dan Dennis K.Davis. (2012). Mass communication theory: Foundations, Ferment, and Future, Sixth edition. Canada: Nelson Education. Ltd. 
Creswell, J. W. (2015). Penelitian Kualitatif dan Desain Riset:memilih di antara lima pendekatan. Edisi Ketiga. Dialihbahasakan oleh Ahmad Lintang Lazuardi Pustaka Pelajar: Yogyakarta. . (2016). Research Design: Pendekatan Metode Kualitatif, Kuantitatif, dan Campuran. Edisi Keempat. Dialihbahasakan oleh Achmad Fawaid dan Rianayati Kusmini Pancasari. Pustaka Pelajar: Yogyakarta.

Direktorat Jendral Pendidikan Tinggi. (2004). Perpustakaan Perguruan Tinggi: Buku Pedoman. Jakarta: Departemen Pendidikan Nasional.

Efendi, Mohammad. (2009). Pengantar Psikopedagogik Anak Berkelainan. Jakarta: PT Bumi Aksara.

Hartono, Bambang. (2010). Pelaksanaan Pendidikan Agama di Sekolah Luar Biasa: Kajian di Tiga Propinsi Indonesia: Kalimantan Barat, Bali, dan Nusa Tenggara Timur. Semaraang: Balai Penelitian dan Pengembangan Agama.

International Federation of Library Associations and Institutions (IFLA). (2014). "IFLA/UNESCO Manifesto for Digital Libraries". Diakses pada 6 Juni 2018 pukul 08.00 WIB dari https://www.ifla.org/files/assets/digital-libraries/documents/ifla-unescodigital-libraries-manifesto.pdf.

Johnson, P. (2004). Fundamentals of Collection Development and Management. USA: American Library Association (ALA).

Mishra, R.K. (2016). "Digital libraries: definitions, issues, and challenges". Diakses pada 6 Juni 2018 Pukul 12.11 WIB dari https://innovareacademics.in/journals/index.php /ijoe/article/download/12997/5665.

Nurlistiani. (2017). "Transformasi Perpustakaan Perguruan Tinggi di Indonesia: Tantangan dan Peluang Perpustakaan Digital Menuju ELearning, E-Research, dan Information Literacy di Perguruan Tinggi". Diakses pada 07 Juni 2018 pukul 08.55 WIB dari http://kpdi9.perpusnas.go.id/HTML5 /Prosiding\%20KPDI\%209.pdf.

Ormrod, Jeanne Ellis. (2008). Psikologi Pendidikan Membantu Siswa Tumbuh dan Berkembang, judul asli: Educational Psychology Developing Learners, alih bahasa: Dra. Wahyu Indianti, M.Si. dkk. Jakarta: Erlangga.

Pendit, P.L. (2008). Perpustakaan Digital dari A sampai Z. Jakarta: Citra Karyakarsa Mandiri.

Potter, W.J. (2004). Theory of Media Literacy: a Cognitive Approach. California: Sage Publication. Inc.

Potter, W. James. "Media Literacy." 21st Century Communication: A 
Reference Handbook. 2009. SAGE Publications. 13 May. 2010. Diakses pada tanggal 2 Oktober 2018 pukul 08.00 dari <http://www.sageereference.com/communication/Article_n62.html\&gt;

Smart, Aqila. (2010). Anak Cacat Bukan Kiamat: Metode Pembelajaran dan Terapi untuk Anak berkebutuhan Khusus. Yogyakarta: Ar-Ruzz Media.

Somantri, Sutjihati. (2007). Psikologi Anak Luar Biasa. Bandung: PT. Refika Aditama.

Sun, J dan Yuan, B.Z. (2012). Development and Characteristic of Digital Library as a Library Branch, diakses pada 6 Juni 2018 Pukul 09.05 WIB. dari http://www.sciencedirect.com/ science/article/pii/S2212667812000524

Witten, I. H., Bainbridge, David dan Nicholas, David M. (2010). How to Build a Digital Library. USA: Elsevier.Inc.

Xie, I., dan Matusiak, K. (2016). Discover digital libraries: theory and practice. USA: Elsevier. Inc

Yusup, P. M. (2016). Ilmu Informasi, Komunikasi, dan Kepustakaan. Jakarta: Bumi Aksara. 